\title{
Contradictory Explorative Assessment. Multimodal Teacher/Student Interaction in Scandinavian Digital Learning Environments
}

\begin{abstract}
Susanne Kjällander
Correspondence: Susanne Kjällander, PhD and Visiting Scholar, Graduate School of Education, Stanford University, USA; PhD and Senior Lecturer, Dept. of Child and Youth Studies, Stockholm University, Sweden.
\end{abstract}

Received: December 6, 2017

doi:10.11114/jets.v6i2.2958

\author{
Accepted: January 14, 2018 Online Published: January 27, 2018
}

URL: https://doi.org/10.11114/jets.v6i2.2958

\begin{abstract}
Assessment in the much-discussed digital divide in Scandinavian technologically advanced schools, is the study object of this article. Interaction is studied to understand assessment; and to see how assessment can be didactically designed to recognise students' learning. With a multimodal, design theoretical perspective on learning teachers' and students' modes are documented and analysed. Illustrated in the article, is how the subject design aims at an expert level, while formative assessment aims at a novice level leaving students without adequate guidance. Despite this, summative assessment aims at an expert level and is at times contradictory. A concluding suggestion is that assessment in a digital learning environment can be designed exploratory to encompass students' new knowledge and to embrace their multimodal signs of learning, or much of what is learned will be ignored.
\end{abstract}

Keywords: learning, digital learning resources, multimodality, social science, designs for learning, education, assessment

\section{Didactic Design of Assessment in the Digital Divide}

Despite thoughts and predications about an assessment revolution driven by technology, education assessment has not really changed nor developed considerably (c.f. Mogey, 2011). Teachers tend to test modes such as texts and speech rather than graphical or audio modes that students, given the choice, prefer to use (Prensky, 2001). This can be referred to as a "digital divide" (Prensky, 2001) between generations and this article studies interaction in assessment actions in and beyond this digital divide (Selwyn \& Facer, 2009). Teachers' assessment of students' representations is studied and an attempt to find out how students make meaning in assessment actions is made. Consequences of assessment for the didactic design of the subject area is highlighted in this article. Selander (2008a) means that digital learning resources change learning in school. Learning becomes a question about how students increase their abilities to use and develop the resources that are at hand in the specific learning situation (Rostvall \& Selander, 2008). Information in schools used to be arranged for the students, but in the digital learning environment it is more and more arranged by the students (Selander, 2008a). Digital learning resources offer new and different potentials for meaning making. Students can engage in a digital situation differently as to how or when they enter it, what details they choose to engage in, what path they choose through it and how they transform and form the information, in other words, how they design and re-design the information. Students construct the information when engaging with it (Jewitt, 2006) and can therefore be producers rather than consumers of digital media. In the digital learning environment, not only teachers but also students are therefore didactic designers (Selander, 2009). When arranging the subject area beforehand, the teacher can have exclusive influence on the design of the framework, but as soon as the students are engaged they transform and form it according to their own needs and interests. Students' interests often have to do with images, animations, sounds, colours and symbols that they are confronted with on the Internet - information that is hard for the teacher to predict. Earlier research indicate that teachers are insecure on whether students really know something when they are working with digital resources and the Internet (Aargaard \& Lund, 2013) and multimodal representations have been proven difficult to assess, since they are viewed as complex and hard to capture and the criteria does not capture the skills visible in students' multimodal texts (Hernwall et al. 2016). A paradox is here that young people are sometimes (wrongly) viewed as naturally digitally competent (cf. Prensky, 2001; cf. Facer, 2012). Although learning in a digital environment is often collaborative, related research indicate that assessment often focus on students' behaviour or their representations (McAlpine, 2012), although the process and formative assessment is often seen as a key to learning (Black \& Wiliam, 1998; 2009). Thus, assessment is often a delicate issue in the digital learning environment. 


\section{Aims and Research Questions}

Students' and teachers' assessment interaction with each other, and with digital learning resources - when teachers and students are designing the subject area together, is a focal point in this article. The article illustrates how assessment can be didactically designed to recognise students' learning by means of their signs of learning and representations as shown by different modes. The study scrutinizes students meaning making in the act of assessment and the consequences of assessment actions and possible research questions are: Within which modes is formative and summative assessment made? Are modes contradictory? What is recognised as learning and what modes are given recognition in the act of assessment? With what modes do students make meaning in the act of assessment? What are the consequences of assessment for the didactic design of the subject area?

\section{Multimodality and Material Studied}

Here, a brief introduction to theoretical standpoints and methodology and ethics of importance is presented.

\subsection{Modes, Meaning-Making and Learning}

The theoretical approach derives from a multimodal, design theoretical perspective on learning - designs for learning (Kress, 2010; Selander, 2008b; Selander, 2017) ${ }^{1}$. Modes are resources that have been historically, culturally and socially formed and organized for communication (Kress, 2003). Modes such as gestures, texts, facial expressions, sounds, and speech are frequently used modes in face-to face communication (Kress, 2010). In a digital learning environment, modes such as sound effects, images, symbols, colours and animations are often occurring. Multimodality means that communication occurs in different modes simultaneously. Modes hold possibilities for meaning making and communication of meaning (Kress, 2009, Kress \& van Leeuwen, 2001) and different modes are of different importance in different situations (Kress et al., 2001). Students choose the modes that seem to fit the situation best and make use of them to give form to a message. The affordances and restrictions in the educational setting guide teachers and students to decide what mode to use for what (Kress, 2003). For example, a student can experience something on the computer screen as meaningful when different signs, such as for example the word "Poland" written above a red and white coloured image of the Polish flag, are put in relation to each other. Some modes on the computer screen are more salient (van Leeuwen, 2005, p. 284), as they catch the student's interest by presenting information in colours, moving images or large, bold text. The ensemble of different signs then becomes meaningful to the student (Kress, 2010). Meaning making is thought to occur when the student transforms the impression with different semiotic resources, such as copying the flag image into a PowerPoint presentation. Learning is studied as a sign-making activity, which relates to the social semiotic perspective on meaning-making (Kress \& van Leeuwen, 2001). Knowledge here becomes the ability to take an active interest in a social domain - such as a discussion about the colours of the Polish flag. Learning thus becomes an increased ability to take an active interest in a social domain (Selander, 2009), or more specific to use and elaborate an established set of signs within a certain domain in a meaningful way, such as being able to identify the Polish flag at a web site and then draw it in a drawing program.

\subsection{Prompts}

Teaching activities can frame what is possible for the student to make meaning from. The teachers set up conditions for the student's learning and force or promote the student to focus on certain things by giving them prompts that they choose, or choose not, to respond to. Interaction is a response to a prompt (Kress, 2010:32). Prompts can be formed in one or several modes. A potential prompt can be a sigh made by the teacher as the student forgot what to say while he or she is making a presentation in class. But, a prompt is not turned into a prompt until the learner appreciates the potential prompt, in this case the sigh, as a trigger to some sort of an action (Kress, 2010), such as starting to read on a piece of paper. As the criterion of a prompt is not that it is meant to be a prompt, but that it becomes a prompt when the learner notices it as a prompt, teachers' interventions can not always be understood as prompts. Didactic processes include a framing which in this specific study means that students make (and are supposed to make) meaning in the knowledge domain of Geography in Social Science. When the teacher hands out a paper with the curriculum objectives in Geography to introduce the subject area, it can be appreciated as a prompt by some students, while the paper might pass by unnoticed by some other students.

\subsection{Levels of Assessment}

Meaning-making and learning in a goal oriented school, can never be totally detached from teachers' judgement (Selander, 2009). The research field of assessment of learning is large and there are many different views on assessment. Criteria corresponding to different grade levels are a common approach in assessment strategies worldwide. These levels often begin at a novice level and end at an expert level (Lindström, 2002), although those words are not always

\footnotetext{
${ }^{1}$ For a description of the design theoretical perspective, see Selander, $2008 \mathrm{~b}$.
} 
used. The lowest - novice - level is about answering simple tasks and doing no more than the teacher asks for. This level includes support by the teacher. The highest - expert - level is about engaging in complicated problems with self-confidence. Students at this level develop their work on their own, finding new problems to solve, searching for models and motivating their choices (Lindström, 2002). Some criticism against levels must be mentioned though and, as Wiliam (2017) mean, assessment indicating how far from a desired level a student is, can provide useful clues, but since all students will not progress through stages similarly, if at all, it can be delicate. However, assessment is often divided into formative and summative assessment (Black \& Wiliam, 1998; 2009).

\subsection{Design Theoretical Perspectives on Assessment}

Evaluating and assessing learning is often a complex and complicated act. Signs made outwardly are, according to Kress (2010) the best evidence the teacher can get for understanding the students' inner process of learning. Signs can be articulated inwardly as when the student is interpreting and trying to understand the meaning of a table found on a website or outwardly as when the student draws an image based on the table (cf. Kress, 2003, p. 37). Sometimes this process is referred to as if the student makes meaning in two rounds; first inwardly and then outwardly (Kress, 2010). In this study, I use the definition of assessment of learning as "understanding signs of learning, as shown by different communicative modes" (Björklund-Boistrup \& Selander, 2009, p. 2). Formative assessment is here understood as frequent, interactive assessments of students' signs of learning during a process to identify learning needs and to support learning (Selander \& Svärdemo-Åberg, 2009, c.f. Black \& Wiliam, 1998: 2009) and summative assessment is here understood as assessment actions after a learning process, most often made as an assessment of the product (Selander \& Svärdemo-Åberg, 2009).

\subsection{Assessment in Learning Design Sequences}

A model for analysis, called a Learning Design Sequence - LDS - is used in this study. It is based on a perspective of learning as a multimodal sign-making procedure ${ }^{2}$. An LDS in a digital learning environment is framed by: learning resources such as computers, digital cameras, mobile phones; purpose, such as objectives and criteria concerning the subject area/ICT and institutional norms, such as, that students shall use their computers for school work, rather than for chatting.

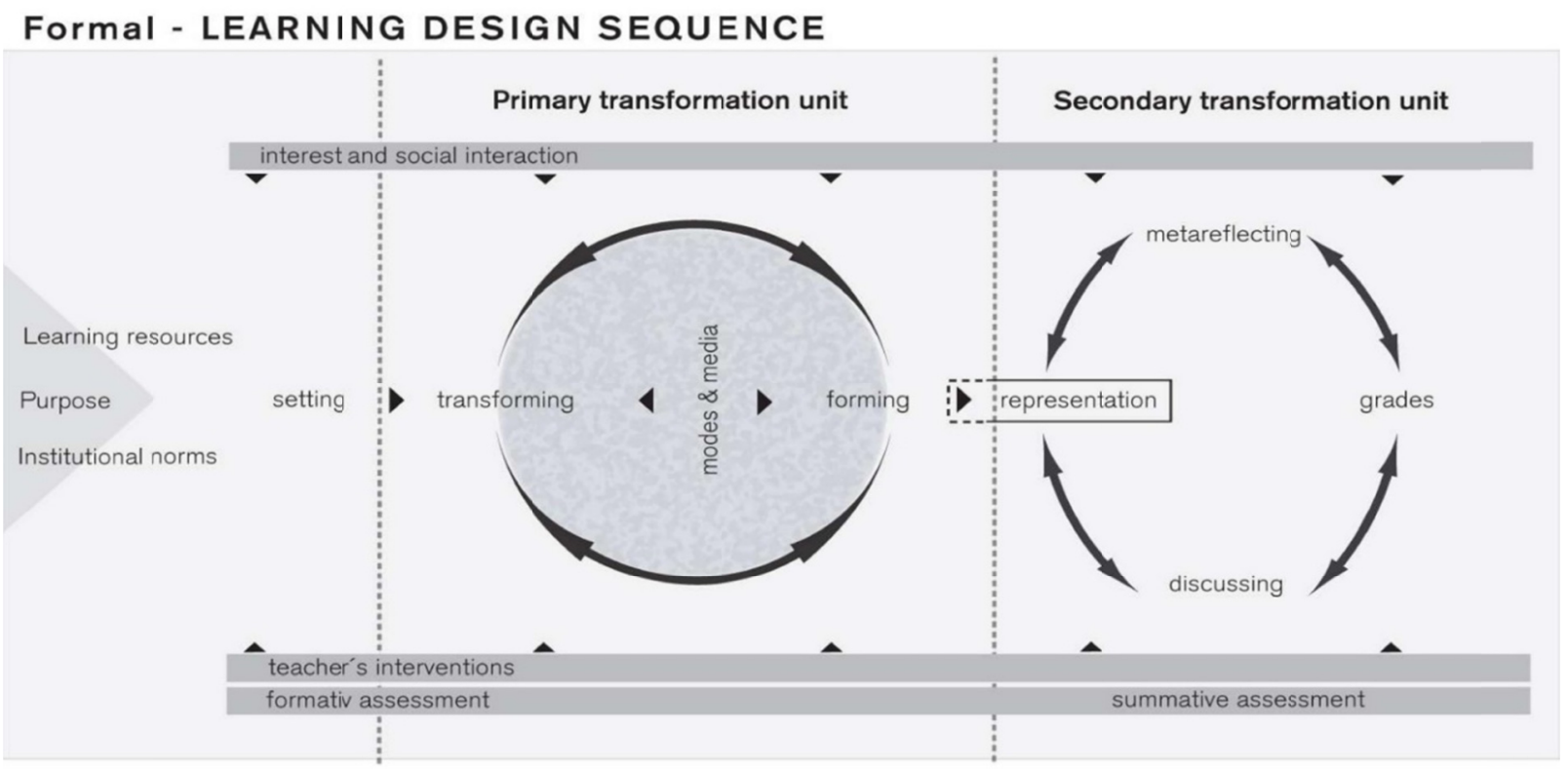

Figure 1. The analytical model Learning Design Sequence (Selander, 2008b)

In the following paragraphs, the notions of the LDS will be discussed with reference to formative and summative assessment. As visualised in the model there is not a sharp line between formative and summative assessment, instead formative assessment can have summative aspects and vice versa. An LDS begins with an introduction of a new subject area. At the beginning of the primary transformation unit, students interpret the task given in the setting and begin transforming information and, based on their own interests, forming knowledge with different modes and media. Media is here the meaning-making, actional, visual and linguistic resources (Kress et al, 2001) that teachers and students use to

${ }^{2}$ For a complete description of the model, see Selander, $2008 \mathrm{~b}$. 
communicate. Digital learning resources can offer potentials for students to work with realistic multimodal simulations of the world around them (Shaffer, 2006b). Computers and the internet make a wide repertoire of representational and communicative modes available (Jewitt, 2006) such as colours, letters, images, sound, questions, notes, words (Kress, 2003; Selander, 2008b). These meaning potentials are historically and socially developed and inherent in a mode. Affordances, on the other hand, are the potential uses of a given object (Gibson, 1979). Different modes in the computer offer different potentials and impose different limitations for meaning making and interaction (Kress \& van Leeuwen, 2006; Kress, 2009). Affordances embrace meanings that have not yet been recognized (van Leeuwen, 2005, p. 5) and different students recognize and comprehend different affordances that they explore and make use of. What the students recognise as an affordance in a specific mode depends on the students' needs, interests and on the specific situation at hand (van Leeuwen, 2005:4-5). Learning is here related to what the student in one way or another presents in different semiotic systems such as body positions, digital photos, sms, drawings, maps, postings in chat rooms, speech and smileys. It does not focus on what is only to be found inside the student's mind - the "internal signs" since this is difficult to document. Instead focus of attention in the act of assessment is the students' "external signs". Signs of learning (cf. Lövgren \& Stolterman, 2004; Rostvall \& Selander, 2008) can be illustrated by the student in a new way to discuss the concept of democracy, a new way to interact with affordances in PowerPoint, a text that proves an increased ability to find information on the Internet or a more detailed image to represent a geographical site. Formative assessment in the primary transformation unit is conducted mainly in teachers' interventions, and teachers assess units of representation during an LDS. Making a representation is a matter of deliberate design (cf. Kress et al. 2001). Formative assessment, on the other hand, is often made in an estimating mode since it is haphazard and not planned in advance by the teacher (OECD, 2005). Instead formative assessment is a natural part of the social interaction between students and teachers and it is often carried out in the interaction between the teacher and one student, as it is difficult to engage a whole group of students in front of the computer screen (Edman-Stålbrandt, 2009). In the interface between the two transformation units, the character of assessment changes to aim at the students' representations. Summative assessment in the secondary transformation unit relates what has been presented in the setting to what has become a part of the student's knowledge. Students seem to be aware of this kind of assessment alone as it is more visible. It is used to measure what students have learned at the end of an LDS, to encourage them or to assure them that they have met grade criteria (OECD, 2005). Discussions and meta-reflections play a decisive role in summative assessment. This kind of assessment considers the whole subject area and the product, and it is normally a planned action initiated by the teacher at the time of the final presentation. The summative assessment can be carried out in interventions but also as grades. If curriculum objectives and grade criteria are defined and explained in the setting, they are often used as a tool for assessing the students summatively.

\subsection{Methodological Considerations}

This research has been funded by a three-year research project called Digital Learning Resources and Learning Design Sequence in Swedish Schools - User's perspective, financed by the research program LearnIT, which is part of the Knowledge Foundation organisation in Sweden. 10 of the most ICT-advanced schools in Sweden participated in this project which includes more than 30 teachers and several hundreds of students and students. More than 60 hours of videotaped material was collected alongside with for example field notes, Mp3-sound-files, interviews, drawings and digital presentations. An entire Learning Design Sequence, from the teacher's introduction to the students' presentation of the final product, has been followed and documented. The research questions, along with the design theoretical, multimodal perspective, required video documentation of classroom interaction to capture different modes in students' "external signs". The video camera facilitates documentation of multimodal interaction (Norris, 2002) and video material opens for an approach whereby visual, action-concentrated and lingual modes are documented simultaneously.

\subsection{A Scandinavian Digital Learning Environment}

The students in this study have a laptop each and are digitally skilled. Teachers tend to view these students as more digitally advanced than they really are, as they seem to be more advanced than the teachers themselves (Prensky, 2001) and according to Facer (2012) young people are often thought to have natural competence in the digital world. These preconceived prejudices are problematic as students might only seem to have advanced digital skills. The UNESCO chair in Global e-Learning states that" Using a computer requires diverse and complex previous knowledge. It also introduces the individual and humanity to new context, which demands mental, intellectual, profound and complex changes." (Varis, 2008, p. 53) and often students lack this kind of depth in technological knowledge. However, the students in this material are comparatively advanced ICT-users and they attend to a school with an ICT-profile. This school takes part in the European Network of Innovative Schools - ENIS ${ }^{3}$ - and has been selected as a front runner, and one of the most innovative schools in Europe. All students are given their own computer when they begin year 4. ICT is

\footnotetext{
${ }^{3}$ More information available on: www.enis.eun.org
} 
used in all subjects, but there is also ICT classes with special course objectives. In year 8 , course objectives have a special focus on digital portfolio, PowerPoint, Moviemaker, Image- and sound control. Multimedia and Excel. All students are given computer diplomas. The school works with all kinds of software such as blogs, wikis, digital individual development plans and digital portfolios. They use the digital resource Skolia ${ }^{4}$, a communication platform for teachers, students and parents. The school pod-casts reviews and lessons in many subjects. '

\subsection{Analysis of Modes in Assessment}

To be able to answer the research questions a multimodal analysis has been designed (cf. Jewitt, 2009) guided by the LDS model. After cataloguing the entire video material (through describing the video sequences according to school subject, age of students, length of LDS and what stage in the LDS the part corresponds to), the specific film material of the subject area is viewed to find sequences with a defined beginning and a defined ending (cf. critical incidents, Flanagan, 1954, Tripp, 1993). According to Norris (2002:99) social interaction is framed by an opening and a closing of the interaction between the participants. The concept of a site of engagement (Scollon, 2001a, Matusov, 2007) offers the opportunity to focus on concrete real-time processes in the material. Such a site of engagement can begin when a student calls for the teacher's attention by raising his hand to ask a question such as "Can I write about it like this? and ends when the teacher formatively assesses the student with words like "That's an interesting event you have written about. Well done!" Sequences that are considered useful to answer the article's specific research questions are selected. A critical incident in this study is 20-180 seconds long. The unit of analysis in this study is interaction between students and teachers and the variables are modes they are using in their interaction. The critical incident is transcribed in detail in a transcription scheme where the text interprets and represents the event - it is not the event itself (Green et al., 1997, Rostvall \& West 2005). The method of multimodal transcription has been chosen since modes give the opportunity to divide activities in the setting into sections to understand them better. All communicational and representational modes have been transcribed but similar modes are put together in columns (such as mimic and gaze) to increase transparency in the chart. Body position, gestures and movements are transcribed in words describing the movement itself, leaving out interpretative descriptions as much as possible. These modes are also visualised by images from the video film. Mimic and gaze are transcribed to understand what the student express and what he/she is looking at. Speech and sound are transcribed inspired on a method called Jeffersonian Transcription Notation ${ }^{5}$.

Table 1. Transcription Guide

\begin{tabular}{ll}
\hline \multicolumn{2}{l}{ Transcription notes } \\
\hline text & speech as in written language \\
$! ?$ & signs as in written language \\
{$[$ text $]$} & overlapping speech \\
(text) & unidentified speech/sound \\
$\ldots$ & pause \\
XX & interrupted speech \\
TEXT & loud speech \\
\hline
\end{tabular}

Transcribing screen activity is a selective process since modes such as images; texts; colours; animations and layout can not be transcribed in detail, partly because the information would be too dense and partly because the film quality would not allow it. In this study a multimodal, dynamic framework is designed ${ }^{6}$. The multimodal analysis focuses on modes in assessment interactions between students, teachers and digital learning resources related to the subject area they are working on in the digital learning environment. Here it is crucial not to let the didactic question of how they interact cast a shadow on what they interact about. Speech is not predominant and in the following transcription example the participants' body positions and gestures are the openings (c.f. Norris, 2002; Kress, 2010) of most time slots.

\footnotetext{
${ }^{4}$ www.skolia.net

${ }^{5}$ Named after Gail Jefferson. More information on the system available at: www.transana.org

${ }^{6}$ The transcription chart is inspired by Rostvall \& West (2005) and Kress \& van Leeuwen (2001).
} 


\begin{tabular}{|c|c|c|c|c|c|c|c|c|c|}
\hline $\begin{array}{l}\text { Sko_Cåk8_02 00.20.35 } \\
\text { Time }\end{array}$ & $\begin{array}{l}\text { Pupils' body } \\
\text { position/ } \\
\text { gesture }\end{array}$ & $\begin{array}{l}\text { Teacher's } \\
\text { body position/ } \\
\text { gesture }\end{array}$ & $\begin{array}{l}\text { Pupils' } \\
\text { mimic/ } \\
\text { gaze }\end{array}$ & $\begin{array}{l}\text { Teacher's } \\
\text { mimic/ } \\
\text { gaze }\end{array}$ & $\begin{array}{l}\text { Pupils' } \\
\text { speech }\end{array}$ & $\begin{array}{l}\text { Teacher's } \\
\text { speech }\end{array}$ & $\begin{array}{l}\text { Image/text/ } \\
\text { colour etc. on screen }\end{array}$ & $\begin{array}{l}\text { Surrounding } \\
\text { sound/ } \\
\text { speech }\end{array}$ & $\begin{array}{l}\text { Surrounding } \\
\text { movements }\end{array}$ \\
\hline 20.35 & $\begin{array}{l}\text { Sits in front of } \\
\text { his lap top } \\
\text { with his hands } \\
\text { over the } \\
\text { keyboard. }\end{array}$ & $\begin{array}{l}\text { Leans over the } \\
\text { desk with her } \\
\text { hands holding } \\
\text { the desk. }\end{array}$ & $\begin{array}{l}\text { Looks at } \\
\text { the screen. } \\
\text { Inhales } \\
\text { through his } \\
\text { nose. } \\
\text { Makes a } \\
\text { nose } \\
\text { wrinkle. }\end{array}$ & $\begin{array}{l}\text { Looks at } \\
\text { John. }\end{array}$ & & $\begin{array}{l}\text { What you } \\
\text { should do } \\
\text { though is } \\
\text { that you } \\
\text { should } \\
\text { compare it } \\
\text { with } \\
\text { another } \\
\text { country } \\
\text { because a } \\
\text { certain... }\end{array}$ & $\begin{array}{l}\text { Internet explorer. } \\
\text { The Country Guide } \\
\text { log, a menu on the } \\
\text { left, the Polish flag, } \\
\text { written facts on the } \\
\text { right. }\end{array}$ & $\begin{array}{l}\text { A pupil next to } \\
\text { John shouts: } \\
\text { ONE, GURU, } \\
\text { WHERE ARE } \\
\text { YOU GOING? }\end{array}$ & \\
\hline 20.39 & $\begin{array}{l}\text { Looks at the } \\
\text { screen. Sits } \\
\text { still. }\end{array}$ & $\begin{array}{l}\text { Turns her body } \\
\text { towards John, } \\
\text { moving her } \\
\text { head to face } \\
\text { John. Waves } \\
\text { her hand in } \\
\text { circles } \\
\text { between } \\
\text { John's face } \\
\text { and the screen. }\end{array}$ & $\begin{array}{l}\text { Looks } \\
\text { straight at } \\
\text { the screen } \\
\text { and then at } \\
\text { the teachers } \\
\text { hands. }\end{array}$ & $\begin{array}{l}\text { Looks } \\
\text { straight into } \\
\text { John's } \\
\text { eyes. }\end{array}$ & & $\begin{array}{l}\text {...eh, the } \\
\text { numbers } \\
\text { don't say } \\
\text { all that } \\
\text { much if you } \\
\text { don't } \\
\text { compare } \\
\text { them... }\end{array}$ & $\begin{array}{l}\text { A menu pops up in } \\
\text { the centre of the } \\
\text { screen. }\end{array}$ & $\begin{array}{l}\text { Gabriel who } \\
\text { sits in front of } \\
\text { John shouts: } \\
\text { To POLAND! } \\
\text { Then the two } \\
\text { otter pupils } \\
\text { are shouting to } \\
\text { each other. }\end{array}$ & $\begin{array}{l}\text { A pupil in } \\
\text { front of John } \\
\text { stirs in his } \\
\text { chair. }\end{array}$ \\
\hline 20.45 & $\begin{array}{l}\text { Turns his } \\
\text { shoulders, } \\
\text { facing the } \\
\text { teacher. }\end{array}$ & $\begin{array}{l}\text { Leans her } \\
\text { elbows on the } \\
\text { desk, turns her } \\
\text { body to face } \\
\text { the screen, } \\
\text { bending it a } \\
\text { little. }\end{array}$ & $\begin{array}{l}\text { Looks at } \\
\text { the teacher. }\end{array}$ & $\begin{array}{l}\text { Frowns. } \\
\text { Reads from } \\
\text { the screen. }\end{array}$ & $\begin{array}{l}\text { [But I'll } \\
\text { copy } \\
\text { that... ] }\end{array}$ & $\begin{array}{l}\text { [You could } \\
\text { actually } \\
[\mathrm{xx}]]\end{array}$ & $\begin{array}{l}\text { Different options in } \\
\text { the menu is selected } \\
\text { and highlighted. }\end{array}$ & & \\
\hline
\end{tabular}

Figure 2. Multimodal transcription chart

The transcriptions are analyzed to find examples, to visualise interesting features of interaction. The modes the teacher uses when assessing the students are of interest. Another interest concerns the modes that the teacher assesses. The modes students use to make meaning in the assessment actions are also of interest.

\subsection{Ethical Considerations}

Questions of anonymity in the collection and report of visual data is extremely important when studying children (Flewitt, 2005), and so in this study. It is thoroughly designed according to research ethics (The Swedish Research Council, 2011), meaning that authorized letters of information were sent to and signed by all parents of children included in the study, here referred to as informed consent in exploratory with children (Flewitt, 2005), all personal information is coded; photos are manipulated until they are impossible to unidentify; and the empirical material is only used by the research team and kept locked in a safe. Also, the names used in the excerpts are fictitious, or assumed (cf. Løkken \& Søbstad, 1995). 'informed' consent in exploratory research with young children, and considers questions of anonymity when collecting and reporting on visual data.

\section{Modes, Meaning Making and Learning in Assessment Actions}

The results part presents the LDS setting and a few empirical examples to visualise formative and summative assessment actions in the digital divide.

\subsection{Possible Transformation}

The subject area is a one-month project in Social Science, in year 8, with the all-embracing theme of Europe. The teacher in this study designs the project as a narrative with a setting that is reminiscent of what Shaffer (2006a) would refer to as an epistemic computer game that is fundamentally about learning to think in innovative ways, something that is required to manage this subject area. Epistemic computer games are designed around many questions and always have specific rules (Shaffer, 2006a). The teacher introduces the project by inviting the students into a game where Sweden has become unsafe and where the students are ordered to flee to another European country to look for a safer existence. During the project, the teacher poses questions that the students shall answer, and continuous rules about what the students are supposed to "experience" during their travel through Europe. The students work on one computer each in groups of about three and they choose their new haven country. In this article, the escape of the students John, Gabriel and Fred to Poland is closely followed and analysed. They design the subject area in interaction with each other, the digital learning resources and with their teacher and form a digital presentation by transforming information from the Internet. The boys choose to form a PowerPoint in which they engage with, and transform text and images found on, 
among other search engines, Google ${ }^{7}$ and The Swedish Institute of International Affairs' website ${ }^{8}$. They form their own written narrative illustrated by digital photos. They divide the task but interact and collaborate constantly on three or more different digital arenas simultaneously as they have three lap tops and a few other digital learning resources at hand. Interaction modes vary. Sometimes they are all working with different objects on each computer; sometimes they cooperate on one computer. The setting frames possibilities for assessment as it is didactically designed according to school norms, the learning resources being used as well as the curriculum, such as course objectives and criteria. National curriculum objectives of Social Science in Sweden include both Social Science and ICT (Skolverket, 2000/2008). The first subject area objective is: to know the country with regard to geography, culture, food and science. This is also used as grade criterion for the pass level (cf. "novice level", Lindström, 2002). The grade criteria for the highest grade are: to be able to compare conditions and explain differences between different countries in Europe with regard to geography, culture and science (cf. "expert level", Lindström, 2002). ICT is not highlighted in these criteria, but in the national curriculum for Social Science. Earlier research shows that students' participation in assessment and awareness of grade criteria is important for their learning (Björklund-Boistrup, 2008; Gipps, 1994). In this LDS all assignments, objectives and criteria are presented in class as well as published on the school website. The assessment corresponds with the $\operatorname{OECD}(2005$, p. 44) "key elements of assessment" as visualised in the following figure where the key elements are italic:

Table 2. Key elements of assessment

\section{Correspondence with the OECD's six key elements of assessment (OECD, 2005:44)}

1) A classroom culture that encourages interaction is established, since working with digital learning resources encourages interaction and as relationships are more horizontal in the digital school setting.

2) Objectives are established and processed on the school website and in digital portfolios, and tracking of individual progress is available in digital individual development plans. Pupils have constant access to these documents on the school website.

3) Varied instruction is used to meet individual needs as formative assessment is conducted between the teacher and a pupil in a) the establishment; b) in the follow up of individual development plans.

4) Varied approaches to assessing pupils' understanding are used, as assessment is multimodal in the 1:1 setting and since assessment often is implemented individually.

5) Pupils are given feedback on their performances and teaching is adjusted accordingly as teachers and pupils redesign the frames for assessment to fit pupils' learning needs in the 1:1 computing environment.

6) Pupils are actively involved in the learning process through advanced digital information and documentation.

\subsection{Potential Prompts}

The teacher introduces the assignment of the example theme orally with the following words, trying to raise the students' interest and motivation with hand gestures and smiles:

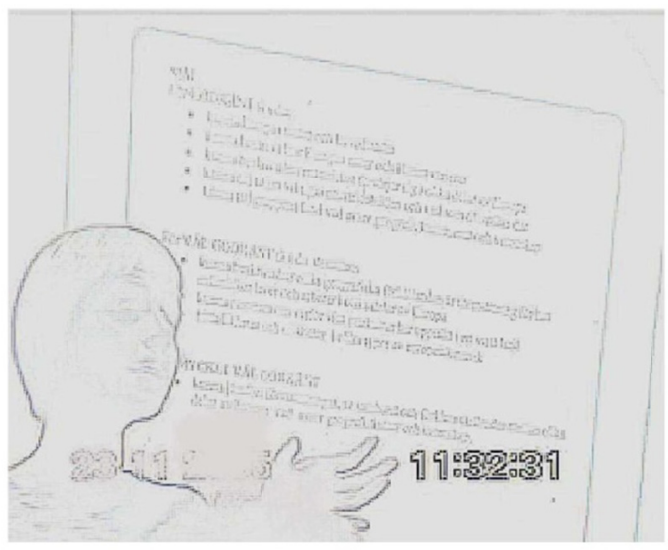

“- As you know, we have objectives for our work now. Objectives and criteria for what we are supposed to attain in terms of knowledge. And you are supposed to know the states and capitals of Europe. And be able to describe how the landscape and climate of Europe vary. Be able to describe how people earn their living in different parts of Europe. And you are supposed to know about some important industrial areas. And you are supposed to know some things about the country you work on in your groups concerning geography, culture, food and science. And we achieved the first four objectives in the basic course, didn't we? When you had homework and I had presentations, and we discussed. Er... but the last objective is what we are doing now, that you will gain knowledge about the geography, culture, food and science of your country."

Figure 3. Transcript of teacher's introduction

\footnotetext{
${ }^{7}$ www.google.se

${ }^{8}$ www.landguiden.se
} 
Although the teacher didactically designs the assignment to raise the students' attention and to make them act in response it does not have to mean that it is appreciated as a prompt by the students, instead they might find a text or an image in the digital interface more interesting and choose to engage in that instead. At the next lesson the students are reminded about one of the course criteria:

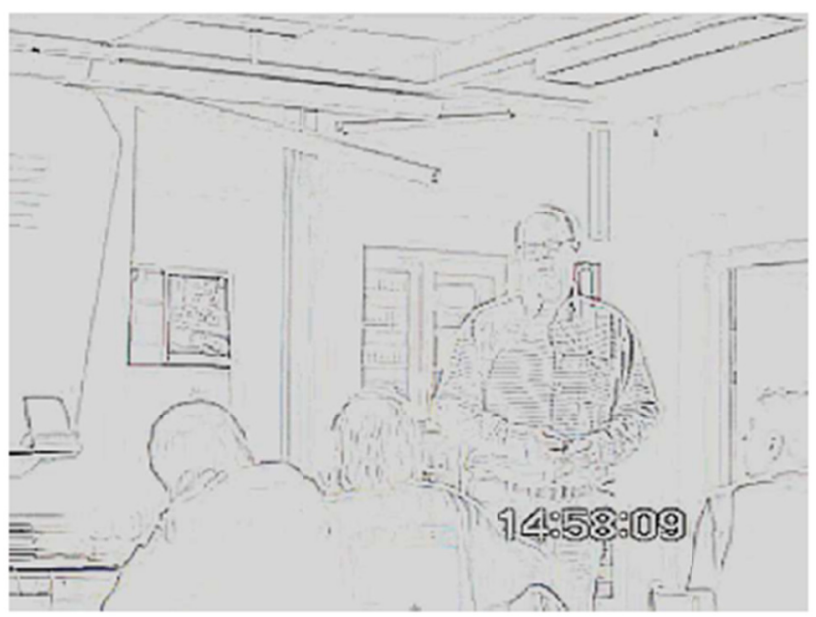

"- Well, this scientist who ... in one way or the other has made a contribution to your country's development. You mustn't forget it. It must be represented in the presentation as well."

Figure 4. Transcript of teacher's formative assessment 1

At this point the three students in the example have already chosen to transform information found on the internet about the Polish politician Leach Walesa and begun forming their own representation, which seems to be a response to an image on the Internet of Walesa that they appreciated as a prompt. The next part shows how this choice is formatively assessed by the teacher.

\subsection{Formative Assessment of Students' Learning Paths}

In this paragraph an example of a formative assessment act will be presented and discussed. Central questions here are; within which modes is formative assessment made and are they contradictory? What is recognised as learning by the teachers and what modes are given recognition in the act of assessment? And with what modes do students make meaning in the act of assessment? A classroom with digital learning resources includes more interaction between teachers and students and in this interaction formative assessment occurs (Holm-Sørensen et al., 2007). The two teachers in this study walk around the classroom, viewing the students' computer screens. Sometimes, by asking a question, a student initiates a discussion that develops into an assessment action; sometimes the teacher approaches students and intervene. The teachers carry out formative assessment - often facing the computer screen. They use words like: "Nice!", "Check that up to make sure it's correct!", "Well, now you've just copied like that, are you going to have a line of reasoning about the whole thing?", "I think that it is good!", "Numbers doesn't say a lot when you don't compare them.", "That's interesting!" "...but you have to understand what it really means..." and "Develop that further!" The teachers assess with gestures like pointing at the screen to indicate a preferred layout; nod to the students' imaginative experiences in Russia; frown to the students' engagement in the design of a digital comparison table between countries; and smile to show approval of a drawn map to visualise their itinerary. Some of these interventions or assessment actions are appreciated as prompts by the students, which mean that they make a sign in response to the teacher's sign (Kress, 2010). To mention an example, the students transform the map into an animation as they interpreted the teacher's signs as an indicator on that he was impressed by their use of the map. There are a few incidents during the Learning Design Sequence where the teacher intervenes by raising the question whether Fred, John and Gabriel are going to use their representation about Walesa, and in that case, "what for?", since it does not answer to the criteria of the subject area. In the following example the objective to present a Polish scientist is formatively assessed. 


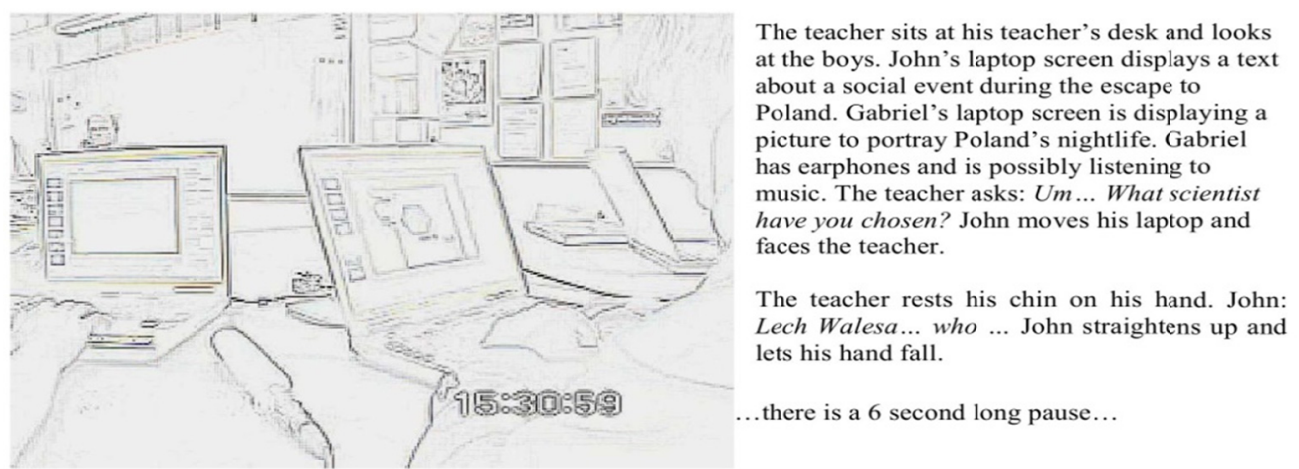

John is typing. Gabriel is moving his shoulders and arms up and down. Gabriel But Fred is the one writing about he, if you want to ask about something! The teacher nods a little in Gabriel's direction: Him!

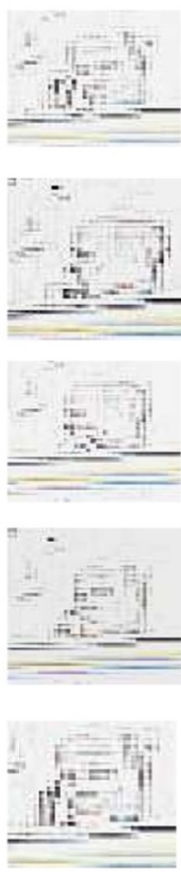

John straightens up and says with a firm and loud voice: Yeah, but he did do something for Poland though. Gabriel is clicking on the touch pad and his screen shows how a whole text is pasted into the PP.

Gabriel is clicking and chooses a new text colour while Fred lifts his head and looks at the teacher: He freed Poland from the communists, right! The teacher turns to look at Fred, nods a little and says: Yes... Gabriel's screen displays the colour palette.

John's screen displays an empty, black PP window. Gabriel is typing, looking closely at the screen which displays the colour of blue and then the whole text as highlighted in red. John: And there aren't many, ma... scientists from Poland, either... The teacher turns away from the pupils and gazes straight ahead. One of the boys is humming quietly.

Figure 5. Transcript of teacher's formative assessment 2

When studying "modes used by the teacher to formatively assess students' meaning making”, we can see that after a pause, the teacher accepts the comment about Poland as a country with few scientists. This acceptance consists of different, but consistent, modes such as speech, humming and nods. However, the 6 seconds long pause, the gaze over the classroom and the repeated touching of his face indicates that he is reluctant at first, to accept the idea of them writing about a politician. Possibly he is annoyed that the boys are not following the rules which might be the reason for him correcting Gabriel's grammar to mark who is in charge, of the didactic design. Perhaps he does it to gain time or just because he appreciates it as his job to correct grammar. In either case, he is thoughtful and considerate when redesigning the frames to fit their representation. He identifies the students' needs and adjusts the teaching accordingly, just as in the OECD definition of formative assessment (OECD, 2005, p. 21).

"Modes formatively assessed by the teacher" can at a first glance seem to be that the teacher only assesses the boys" speech (such as correcting Gabriel's grammar) as he stays in his seat, not even looking at the boys, nor at their digital representations. But when analysing the teachers' different modes, clearly, he recognizes the boy's determination as communicated in different modes such as body position, gaze and voice. These modes are recognised as signs of learning. Formative assessment is in this example also about controlling that the students' representation includes texts about all that is written in the lowest subject area objective and used as a grade criterion for the pass level: to know the country with regard to geography, culture, food and science. In the primary transformation unit, the teacher seems to be formatively assessing the students, compared to a novice level (Lindström, 2002).

The "modes used by the students to make meaning in the formative assessment act" is interesting to study. The students seem to recognize the teacher's hesitation as a prompt. With firm, loud speech, they argue for keeping the part about Walesa in their representation. They use both course objectives and criteria as tools to justify their choice. Fred stresses their argument by straightening up, looking straight at the teacher and John seems to be using his body position and 
gestures to show that he is awaiting the teacher's response. The students must decide what signs from the multimodal arrangement on the Internet to include, and what to exclude, to form their representation (Jewitt, 2003). How well they do this is assessed and compared to grades criteria. Internationally as well as in this subject area, the acts of "learning to learn" and "producing new knowledge" correspond to the highest-grade criteria (Lindström, 2002). This focus is established already in the setting when the teacher with modes such as voice, gestures and body positions indicates her faith in the students' abilities while handing out the instruction telling the students that they shall "...look for a safer existence...", “...spend a lot of time and energy getting to know..." and "...describe the journey..." Instructions of this kind corresponds to criteria often found on the expert level; independent development (such as making up a trip through Europe); finding new problems to solve (such as figuring out how to visualise the trip with images, animation and sounds in PowerPoint); searching for models (such as comparison tables between countries) and motivating their choices (such as motivating the inclusion of the politician) as seen in this example.

What is then "recognised as learning in the primary transformation unit"? Well, the text in the PowerPoint is recognised as beholding the most important signs of learning in the primary transformation unit. Formative assessment in this study is about encouraging students with modes such as smiles, taps on shoulders and compliments, rather than guidance and challenging. These interventions seem to be made with the novice level criteria in mind, as the main issue is to make sure that the PowerPoint includes all parts mentioned in the assignment. Possibly the students are not sufficiently challenged in the assignment at hand and therefore choose to engage in something more exciting and challenging than was framed by the original task. Another reason can be that the students lack experience and knowledge about how to search for adequate information. Learning is thus recognised as partly the text about Europe and partly about learning how to use digital learning resources. The use of technology is understood as skills, rather than knowledge, which "require a dynamic environment in which to capture the practice of these skills in action" (McFarlane, 2003, p. 261). Formative assessment is about identifying students' learning needs, also when it comes to learning how to use the computer. Earlier research suggests that students need more and better organized formative assessment in a digital learning environment since the flow of information radically increase through the combinations of modes and the linking possibilities that hypertext offers (Jewitt, 2003, Edman-Stålbrandt, 2009). Levinsen \& Holm-Sørensen (2008) describes how a teacher's role in the digital learning environment is to give scaffolding interventions, such as helping them search for information on the Internet. The teacher is not supposed to give the students suggestions about different scientists, which the teacher in the example does not do. This is an important element in formative assessment according to the OECD, which presents the concept that formative assessment is about "helping students understand their own learning and develop appropriate strategies for "learning to learn"” (OECD, 2005:23). The students make different choices, based on the content which is successively formed. Choices are important from a design theoretical perspective (Selander, 2009; Selander, 2017) telling us what the student thinks is important. Choices are recognised as signs of learning in this example. The boys know what a scientist is, and they are aware of the grade criteria, which mean that they have made a conscious choice knowing that there is a risk that they might be assessed negatively for presenting a politician. The result of the formative assessment is that the students can write about a politician if they can argue why. The example illustrates how the students design their own learning path due to appreciating the information on the Internet on Walesa as a prompt. The teacher's multimodal assessment act, is yet another prompt to justify their choice. The following example presents how the other teacher summative assesses the same representation in the final representation.

\subsection{Summative Assessment of Students' Representations}

In this paragraph an example of a summative assessment action will be presented and discussed. Within which modes are summative assessment made and are they contradictory? The text will also visualise what is recognised as learning and what modes are given recognition in the act of assessment? Modes, that students use to make meaning of assessment, are studied as well. Proceeding to summative assessment, students are in the second transformation unit of the LDS model. A summative assessment event is designed by the teacher right after John's, Gabriel's and Fred's PowerPoint presentation in class. The summative assessment design begins with a "Pros and cons list" where students are supposed to sum up their different experiences of what they liked and disliked about Poland. They are also supposed to decide whether the pros or the cons carry the greatest weight and if they want to stay in Poland. Second students are supposed to meta-reflect to assess their own contributions and evaluate how engaging as well as how difficult the subject area was. This meta reflection is made in relation to the double set of objectives 1) Social Science, 2) ICT. Finally, the teacher assess the representation by 1) illustrating the students' learning path and 2) lifting a few signs of learning. The following is an excerpt from the students' PowerPoint presentation in class. The bold text is projected on the wall, as well as on a sheet of paper that is read out aloud by the three students sitting at the teacher's desk. One slide in the PowerPoint presentation is missing in the projected version of the document. 


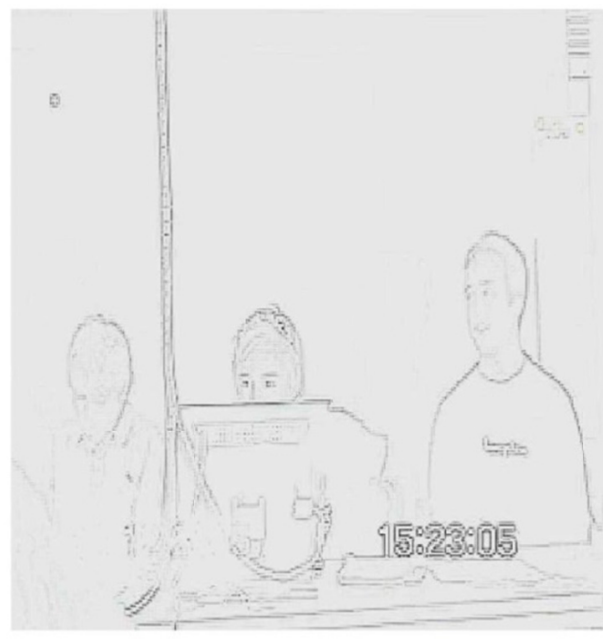

\section{8 with other activists Lech Walesa} started a group that fought for poland to be freed from the communists John: Well, here we had another page and this...Fred: Yeah. John: Well, yeah, a lot really.

Another pupil: But read what you can! Fred: Lech Walesa...John: And the meeting as well... Fred: Yeah, however, he went to prison for that and after that he was released and became the president. After the communists. Gabriel: Yes, Lech Walesa did free them from the communists, so to say... and in 1981 he won the Nobel Peace Prize.

Figure 6. Transcript of students' presentation

The following exemplify the summative assessment of the presentation in class corresponding to the incident described above. The teacher cannot possibly assess every detail in the representation. Instead, she chooses some examples to focus on, due to her interest and the framing of the situation. In this example, both students and teacher, with different modes, put the representation of Lech Walesa to the fore.

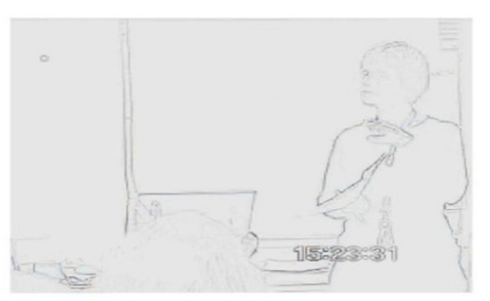

The teacher turns from Fred, takes a few steps to the teacher's desk and moves the papers in her hand: Yes. Was there something that you found... that you found difficult, then? The teacher stands behind the teacher's desk, looking at Fred who answers: Yes, to find a scientist! Gabriel and/or John hums.

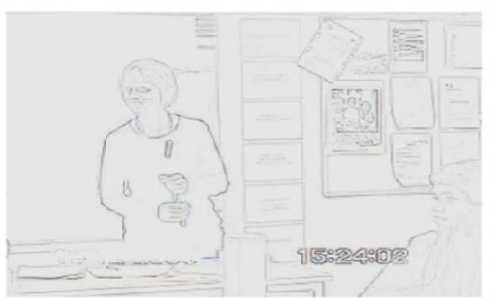

The teacher turns to face Gabriel or John and then turns back to face Fred; Yes, you thought it was difficult to find a scientist. Fred: Yes, it was practically impossible! Gabriel and/or John hums. The teacher smiles and laughs a little and puts the papers on the teacher's desk and nods.

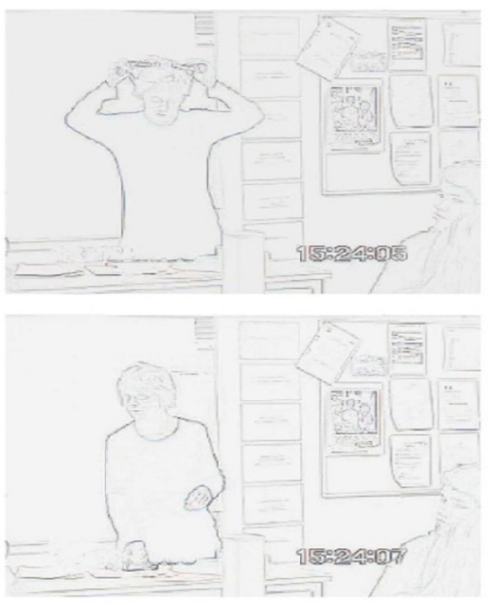

The teacher looks at Fred and begins to fiddle with the keys around her neck and then take the bunch of keys off. She closes her eyes and bends her head down and says: There must be someone? But... That... She nods: What I think was interesting is that you brought up Lech Walesa, nevertheless.

Figure 7. Transcript of teacher's summative assessment

In the following, the "modes used by the teacher to summatively assess students' representation" will be illustrated. The teacher's words confirm that it was difficult to find a Polish scientist, but through other modes such as gestures, mimic and laughter, she shows that she thinks that they have failed in that part of the didactic design. Contradictory assessment is very difficult for students to interpret as they are busy learning a subject (Rostvall, 2008). Both teachers intervened in 
the transformation process when the students were forming their representation about Poland, but the students have nevertheless not included a Polish scientist in their presentation. The teacher looks at the boys with a pleased and interested face, smooth voice and with positive-loaded words such as "interesting" and "important", which indicates that she assesses the students as if they had fulfilled the assignment satisfactorily. Summative assessment in the shape of assessing the product (Selander \& Svärdemo-Åberg, 2009), is in the periphery of the assessment action. Instead, the assessment action in this LDS can be described as interactive assessments of students' signs of learning, and students' creativity is given significance. The teacher indicates that it is a formal assessment situation by standing up, thoroughly viewing the students as they are sitting in their desks. But, with other modes, such as hesitating pauses, fiddling with keys, humming and agreeing nods to the boys' comments, she indicates that the situation is not so formal. The students seem to appreciate this as prompts, to respond by defending their work and criticising the didactic design.

"Modes summatively assessed by the teacher", are the focus in the following critical incident. Here the teacher assesses students' representations as communicated in the modes of speech and texts. How well they have met the subject area objective and now "know the country with regard to geography, culture, food and science" is met in how well they present their PowerPoint orally, not so much in how they represent their understanding in other semiotic sign systems such as colours or images. Earlier research too, shows how engaged students are in the design of the digital representation (Edman-Stålbrandt, 2009). In this example, the didactic design aims not only at reproducing facts, instead both students and teachers stretch and transform the frames to embrace new knowledge. In the act of assessment, the final aim appears as something negotiable. A semiotic, multimodal representation is not supposed to be an exact replica of what the world is like, but a reconfiguring of signs that show how the students, with the cultural resources at hand, understand something. Form and content should thereby not be separated in the assessment actions. Instead, choosing how to express something means choosing what to express (cf. Rostvall \& Selander, 2008). Students show what they understand by showing how they understand it, for example using a dark background and a bold, dramatic font to represent something frightening, such as that Walesa was being imprisoned because of his political views. Modes, other than speech and text, are not assessed although the students deliberately use them to make meaning. The final representation does in many respects correspond to the highest-grade criteria as presented in the subject area objectives as the students with different modes such as comparison tables of their own design and colours to represent feelings shows how they are able to "compare conditions and explain differences..." as written in the subject area grade criteria for the expert level (Lindström, 2002).

Also, there are some interesting results illustrating the "modes used by the students to make meaning in the summative assessment act". Without hesitation and with a dejected, and possibly indignant, voice Fred express the problem they had to meet the assignment to include a scientist. The other students agree by humming, which indicates that they have probably discussed the parts they now mention as problematic. At this point, the interaction, with different sign systems, is transformed into an assessment. Lindström (2002) shows, that it is not unusual that evaluation is a part of the assessment procedure. In this example there is a sliding scale between evaluation and assessment.

The question is what can be "recognised as learning in the secondary transformation unit". Both students' knowledge in ICT and Social Science is recognised as learning in the secondary transformation unit. The result of the study illustrates that the OECD definition of summative assessment as "measuring what students have learned through testing and examination" (OECD, 2005, p. 13) has limitations when students are working with the web. It shows how difficult it would have been for the teacher to embrace and assess the students' signs of learning in different modes with a traditional written test. The phenomenon of "teach to the test" (McFarlane, 2003, p. 261) is therefore not an alternative as the students' interest has guided them to make their own learning paths, meaning that they have transformed and formed unexpected information about Poland in many different modes. In a pre-designed written test most of their signs of learning would have been made invisible. Students' engagement in information search is recognised as learning. On the one hand, the teacher seems provoked by Fred's multimodal statement that it was "almost impossible" to find a Polish scientist, perhaps since this statement could disqualify her didactic design of the subject area. She looks at Fred and says: "There must be someone, alright?" On the other hand, she does not wait for Fred's answer, but instead chooses to assess their creative solution to the problem by finding a politician and incorporate him in the presentation instead.

\section{Discussion: Consequences for Didactic Design of the Subject Area}

This part of the article will discuss meaning making in assessment actions, with a special focus on possible consequences of assessment for the didactic design of the subject area. The examples show how measurement of results is less regulated in the digital environment, resulting in assessment characterized by flexibility. The relationship between students and teachers is changed and becomes more horizontal and equal (Holm-Sørensen, et al., 2007). Characterising for interaction between students and teachers in the digital classroom is that it seems to be more egalitarian and less formal. There is a chance that students understand assessment of learning as informal, which in a 
proper sense it is not. Learning is still the objective of the work and the subject area is just as much designed for learning. Learning is in part the objective with the didactically designed activities (cf. formal learning), but it is also the means for reaching the objective (cf. informal learning) in the subject area that has been designed (c.f. Holm-Sørensen, 2009). Earlier research indicates that tuition in digital learning environments is open and flexible. Students have influence on the problem- and project-based learning (Holm-Sørensen, et al., 2007) and their learning path to the final representation is open and unpredictable (Svärdemo Åberg, 2009), something that is confirmed in this study that also shows that students have influence on the didactic design by means of transforming the frames for assessment. Since students are didactic designers, their interpretation of the subject and the course objectives is crucial. An interpretation (Kress, 2010) means not only that their understanding increases within a certain framework, such as the grade criteria presented by the teacher in the setting; it can also mean that the framework for interpretation is changed by means of the interpretation. When students form their understanding in the subject area, a change, or shift, occurs in the starting point of the interpretation (Selander, 2009); in other words, the students didactically design and transform the framework of objectives and grade criteria while working in the subject area. The study shows how this transformation results in that the teachers extends the frames for assessment to include and to assess the students' signs of learning in politics, probably framed by the course objective "to be able to compare conditions and explain differences between different countries in Europe with regard to geography, culture and science" which means that the frames have been extended to embrace Geography, Culture, Science and Politics. However, it should be emphasized that students cannot change the framework in any direction they want, instead the study shows how the didactic design and the frames for assessment is negotiated in communication between students and teachers.

\section{Conclusion: Exploratory Assessment to Embrace Multimodal New Knowledge}

What is "new" about digital media has to do with speed (Jewitt, 2006). The flow of information in Scandinavian schools is massive, fast and even uncontrollable, so that curriculum objectives and criteria cannot possibly keep up with digital media, as they are developing faster than the curriculum can possibly be updated. According to Jewitt (2003), students' learning with computers includes a special approach to assessment since what is to be learnt is constantly configured by the modes and their arrangement on the computer screen - the teacher and the textbooks are no longer the main source of information. An Internet page about important Polish persons might not have the same content or layout today as it has tomorrow. Black (2015) means that these new practices challenge both teachers and students to re-think their role in assessment acts in the classroom. Earlier research indicates that there are no detailed instructions controlling Swedish schools today, instead teachers, along with their students, must to a large extent shape the school world themselves (Selander, 2009). The digital learning environment is characterized by being knowledge-based, and reflexively researching and developing its own knowledge (Holm-Sørensen, et al., 2007) and this study visualise how assessment has become a matter of grading something unknown. What is recognised as learning by the teacher might not correspond to grades criteria. In the formative assessment acts of this study the students' text in the PowerPoint, the students' engagement with ICT and their conscious choices and oral arguments are recognised as learning. In the summative assessment acts students' ICT skills, oral speech, the text in the PowerPoint, engagement in information search and creative solutions are recognised as learning by the teacher, which becomes a contradiction. The students' engagement with modes such as moving images, photos, colours and layout is not recognised as learning, although this is something that the students are engaged in and spend a lot of time on. Related research illustrates that these kinds of multimodal representations are difficult to assess, since they are viewed as complex and hard to capture (Hernwall et al. 2016) and students learn a great deal in a digital learning environment that is never noticed nor assessed by the teacher since the teacher focuses on the final product (Engström, 2007). Qualitative formative assessment actions during the whole LDS can here be a strategy to embrace signs of learning in the digital interface. This study shows how the teachers' intentions with the didactic design of the subject area aims at that students shall reach the expert level (Lindström, 2002). The summative assessment in this LDS is accomplished with the highest-grade criteria in mind too. But as formative assessment actions, contradictory, aim at the novice level (Lindström, 2002) the students are left without adequate guidance and support during the LDS primary transformation unit where the important transforming and forming of information is made. Assessment in the digital learning environment must be designed to embrace different modes for school to be able to develop. The assessment system is sometimes thought to be a barrier to change, since assessment is trapped in the book age and thus inappropriate in the digital age (Underwood, 2007). Hernwall et al. (2016) mean that curriculum criteria does not really capture all skills visible in students' multimodal texts and this study suggests that there is a need to move beyond modes such as speech and text to be able to understand and assess the complexity of learning. The example in this study visualises that image is beginning to overtake the role of the mode of writing (Selander, 2008a; Kress, 2003), with profound consequences for assessment. An image can be considered more salient (van Leeuwen, 2005:284) than a text as it attracts the viewer's attention. To mention an example, a picture of a politician in front of an enthusiastic crowd of people can be far more informative and meaning making than a written text about the same event. Different signs systems should therefore be observed as if they have the same status. Students in this 
subject area have designed their representation with modes such as speech, colours, layout, photos, maps and text. This has consequences for how learning ought to be assessed. "If learning is multimodal and assessment is restricted to the modes of speech and writing the assessment will ignore (and in the process negate) much of what is learnt." (Jewitt, 2003:84).

\section{Final Remarks}

This study suggests that assessment can be designed exploratory (Quellmalz \& Kozma, 2003, p. 405). Since learning in this article is described as an increased ability to take an active interest in a social domain in a worthwhile approach (Selander \& Kress, 2010), it is also about producing new knowledge. If assessment is not designed exploratory to embrace new knowledge, innovation risks to be inhibited by the assessment act (OECD, 2005) in the digital divide (Prensky, 2001; Selwyn \& Facer, 2009). Embracing new knowledge initiates shared control which can, according to Facer (2012) potentially create education based on democracy. Teachers are often insecure on students' knowledge in the digital learning environment (Aargaard \& Lund, 2013) - but perhaps an exploratory approach might be a solution. Quellmalz and Kozma (2003) present crucial parts to include in an exploratory assessment design of students' learning in the digital learning environment. They suggest that students ought to be assessed according to how they; collaborate and plan strategies; access and organize information; represent and transform information; analyse and interpret information; test their own strategies for analysis and interpretation; plan a presentation to communicate their results and to evaluate other's work critically. These points do in many ways answer to what the design of objectives and criteria (at the expert level) aim at in this study, and can serve as a guide to how assessment actions could be successfully designed in the digital learning environment with one crucial addition. This study shows that assessment in the digital interface must embrace students' signs of learning in more modes than the lingual since students' signs of learning can be visualised in what they say or write but more often in, for example, how they navigate on the internet; what colours and layout they choose to represent something in a PowerPoint presentation; or what background music they choose for a digital film. These kinds of practices of assessment, can possibly help the students to become thoughtful and independent learners, as described by Black (2015).

\section{Acknowledgements}

I would like to thank all the students, teachers and my fellow research colleagues that made this study possible.

Dr Kjällander want to thank "Riksbankens Jubileumsfond (RJ), The Swedish Foundation for Research in the Humanities and Social Sciences" ([http://www.rj.se)]www.rj.se) for making this article possible.

\section{References}

Aagaard, T., \& Lund, A. (2013). Mind the gap: Divergent objects of assessment in technology-rich learning environments. Nordic Journal of Digital Literacy, 8(04), 225-243.

Björklund-Boistrup, L. (2008). När Kicki tog körkort: En bedömning av elevers lärande. In: Rostvall, A-L. \& Selander, S. (red.). (2008) Design för lärande. Stockholm: Norstedts Akademiska Förlag.

Björklund-Boistrup, L., \& Selander, S. (2009). Coordinating multimodal social semiotics and institutional perspective in studying assessment actions in mathematics classrooms. In: Proceedings of CERME 6, Sixth Conference of European Research in Mathematics Education Lyon, France - Jan.,28th - Feb., 1 , 2009.

Black, P. (2015). Formative assessment-an optimistic but incomplete vision. Assessment in Education: Principles, Policy \& Practice, 22(1), 161-177. https://doi.org/10.1080/0969594X.2014.999643

Black, P., \& Wiliam, D. (1998). Assessment and classroom learning. Assessment in education, 5(1), Oxfordshire UK: Carfax Publishing Ltd. https://doi.org/10.1080/0969595980050102

Black, P., \& Wiliam, D. (2009). Developing the theory of formative assessment. Educational Assessment, Evaluation and Accountability, 21(1), 5-31. https://doi.org/10.1007/s11092-008-9068-5

Edman-Stålbrandt, E. (2009). Scaffolding - om att stötta lärande i arbete med digitala redskap. In: Selander, S \& Svärdemo-Åberg, E (red.) Didaktisk design i digital miljö - nya möjligheter för lärande. Stockholm: Liber.

Engström, S. (2007). The digital learning resource - a tool, content or a peer? Digital media in Learning Design Sequences. Stockholm: The Stockholm Library of Curriculum Studies.

Facer, K. (2012). Taking the 21st century seriously: young people, education and socio-technical futures, Oxford Review of Education, 38(1), 97-113. https://doi.org/10.1080/03054985.2011.577951

Flanagan, J. C. (1954). The Critical Incident Technique. Psychological Bulletin. 51(4), 327-359. https://doi.org/10.1037/h0061470

Flewitt, R. (2005). Conducting research with young children: Some ethical considerations. Early Child Development and Care, 175(6), 553-565. https://doi.org/10.1080/03004430500131338 
Gipps, C. (1994). Beyond Testing. Towards a theory of educational assessment, London: The Falmer Press.

Hernwall, P., Insulander, E., Åkerfeldt, A., \& Öhman, L. (2016). Bedömning av multimodala elevarbeten - lärares uppfattning om bedömning. In: Nygårds, K. \& Raymond, T. (red.). Navigera i den digitala samtiden. Lärarförlaget.

Holm-Sørensen, B. (2009). Didaktisk design för serious games. In: Selander, S. \& Svärdemo-Åberg, E. (red. 2009). Didaktisk design i digital miljö. Nya möjligheter för lärande. Stockholm: Liber.

Holm-Sørensen, B., \& Levinsen, K. T. (2008). It faglig laring og paedagogisk videnledelse. Forskningsrapport vedr. Projekt It Læring 2006-2007. København: DPU, Aarhus Universitet/Gentofte Kommune.

Holm-Sørensen, B., Danielsen, O., \& Nielsen, J. (2007). Children's informal learning in the context of school of knowledge society. Education and Information Technologies, 12(1).

Jewitt, C. (2003). Re-thinking Assessment: multimodality, literacy and computer-mediated learning, Assessment in Education: Principles, Policy \& Practice, 10(1), 83-102. https://doi.org/10.1080/09695940301698

Jewitt, C. (2006). Technology, literacy and learning. A multimodal approach. London: Routledge.

Jewitt, C. E. (2009). The Routledge Handbook of Multimodal Analysis. London/New York: Routledge.

Kress, G. (2003). Literacy in the new media age. London: Routledge. https://doi.org/10.4324/9780203164754

Kress, G. (2009). What is mode? I: Jewitt, C. Ed (2009) The Routledge Handbook of Multimodal Analysis. London/New York: Routledge.

Kress, G. (2010). Multimodality. Exploring Comtemporary Methods of Communication London: Routledge.

Kress, G., \& van Leeuwen, T. (1996). Reading images: the grammar of visual design. London: Routledge.

Kress, G., Jewitt, C., Ogborn, J., \& Tsatsarelis, C. (2001). Multimodal teaching and learning. The rhetorics of the science classroom. London, New York: Continuum.

Lindström, L. (2002). Produkt- och processvärdering i skapande verksamhet. In:Att bedöma eller döma. Tio artiklar om bedömning och betygssättning. Stockholm: Skolverket.

Løkken, G., \& Søbstad, F. (1995). Observation och intervju i förskolan. Studentlitteratur.

Lövgren, J., \& Stolterman, E. (2004). Thoughtful interaction design. A design perspective on information technology. Cambridge, Mass.: The MIT Press.

Matusov, E. (2007). In Search of the Appropriate' Unit of Analysis for Sociacultural research. Los Angeles, London, New Delhi, Singapore: SAGE Publications.

McAlpine, M. (2012). Collaborative assessment and the assessment of collaboration. International Journal of e-Assessment, 2(2).

McFarlane, A. (2003). Editorial. Assessment for the Digital Age. Assessment in Education, Vol. 10, No.3, November 2003, Taylor \& Francis Ltd. https://doi.org/10.1080/0969594032000148127

Mogey, N. (2011). 'What is it that is really acting as a barrier to widespread use of summative eassessment in UK higher education?' International Journal of e-Assessment, 1(1).

Norris, S. (2002). The implication of visual research for discourse analysis: transcription beyond language. Visual communication, 1(1), 97-121. London: SAGE Publications. https://doi.org/10.1177/147035720200100108

OECD (2005). Formative assessment: improving learning in secondary classrooms. Paris: Organisation for Economic Co-operation and Development.

Prensky, M. (2001). Digital Natives, Digital Immigrants From On the Horizon (MCB University Press, 9(5), October 2001)

Quellmalz, E., \& Kozma, R. (2003). Designing Assessments of Learning with Tehcnology. Assessment in Education, 10(3), Taylor \& Francis Ltd. https://doi.org/10.1080/0969594032000148208

Rostvall, A. L. (2008). Möten och metaforer. In: Rostvall, A-L. \& S. Selander (red.) Design för lärande, 81-96. Stockholm: Norstedts Akademiska Förlag.

Rostvall, A. L., \& West, T. (2005). Theoretical and Methodological Perspectives on Designing Video Studies of Interaction. International Journal of Qualitative Methods, 4(4), December 2005. https://doi.org/10.1177/160940690500400406

Selander, S. \& Kress, G. (2010). Design för lärande - ett multimodalt perspektiv. Lund: Studentlitteratur 
Selander, S. (2008a). Pedagogiska texter - ett sätt att designa lärprocesser”. In: Rostvall, A-L. \& S. Selander (red.) Design för lärande, 28-45. Stockholm: Norstedts Akademiska Förlag.

Selander, S. (2008b). "Tecken för lärande - tecken på lärande. Ett designteoretiskt perspektiv". I Rostvall, A-L. \& S. Selander (red.) Design för lärande, 81-96. Stockholm: Norstedts Akademiska Förlag.

Selander, S. (2009). "Didaktisk design.” In: Selander, S. \& Svärdemo-Åberg, E. (red) Didaktisk design i digital miljö nya möjligheter för lärande. Stockholm: Liber.

Selander, S. (2017). Didaktiken efter Vygotskij - Design för lärande. Stockholm: Liber.

Selander, S., \& Svärdemo-Åberg, E. (red) (2009). Didaktisk design i digital miljö - nya möjligheter för lärande. Stockholm: Liber.

Selwyn, N., \& Facer, K. (2009). Beyond digital divide: towards an agenda for change. Handbook of research on overcoming digital divides: constructing an equitible and competitive information society. Hershey: Information Science Reference, 1-20.

Shaffer, D. W. (2006a). How computer Games Help Children Learn. Palgrave: Macmillan. https://doi.org/10.1057/9780230601994

Shaffer, D. W. (2006b). Epistemic frames for epistemic games Original Research Article Computers \& Education, 46(3), 223-234.

Svärdemo-Åberg, E. (2008). The pattern of social interaction influencing students' work at computers: A study of interaction and use of digital learning resources within a Learning Design Sequence. Design for learning, 2008(1), 2.

The Swedish Research Council. (2011). Good Research Practice. The Swedish Research Council's expert group on ethics. Head: Göran Hermerén. 1:2005 in the Swedish Research Council's report series, Bengt Gustafsson, Göran Hermerén and Bo Pettersson.

Tripp, D. (1993). Critical incidents in teaching: developing professional judgement. London: Toutledge.

Underwood, J. D. M. (2007). Rethinking the Digital Divide: impacts on student-tutor relationships. European Journal of Education, 42(2), 2007. Oxford: Blackwell Publishing Ltd. https://doi.org/10.1111/j.1465-3435.2007.00298.x

Varis, T. (2008). European and global approaches to digital literacy. Digital kompetanse, Nordic Journal of Digital Literacy, 3, 1-2008.

Wiliam, D. (2017). Assessment and learning: some reflections. Assessment in Education: Principles, Policy \& Practice, 24(3), 394-403. https://doi.org/10.1080/0969594X.2017.1318108

\section{Copyrights}

Copyright for this article is retained by the author(s), with first publication rights granted to the journal.

This is an open-access article distributed under the terms and conditions of the Creative Commons Attribution license which permits unrestricted use, distribution, and reproduction in any medium, provided the original work is properly cited. 